\title{
Effect of saturation degree of recycled aggregates \\ on concrete properties
}

AbdulKader El MIR - Ph.D. student, BME Department of Construction Materials and Technologies - abdelkader.elmir@hotmail.com

GásPÁR BALCZÓ - BSc student, BME Department of Construction Materials and Technologies

- balczog@gmail.com

SALEm Georges NEHME - Associate professor, head of laboratory, BME Department of Construction Materials and Technologies • sgnehme@yahoo.com

Érkezett: 2015. 04. 10. - Received: 10. 04. 2015. - http://dx.doi.org/10.14382/epitoanyag-jsbcm.2015.9

\section{Abstract}

Concrete imposes a significant effect on the environment due to the production of its components. Hence the direction today is targeted towards construction demolition waste and the methodology of enhancing the quality and quantity of recycled aggregates. This paper evaluates the implementation of crushed brick as coarse and fine aggregate for the replacement of natural aggregate in two separate water absorption conditions ( $7 \%$ air-dry and fully moist aggregates). The waste of crushed bricks was sieved and re-mixed in order to obtain the required gradation fractions $(0-4 ; 4-8 ; 8-16 ; 16-32 \mathrm{~mm})$. In different percentages, natural coarse and fine aggregates were substituted by crushed bricks aggregates (0, 55 and 75\%). Laboratory tests were performed at the BME, Department of Construction Materials and Technologies. Aim of the study is to examine some concrete properties (compressive strength, surface hardness and watertightness) for both natural and recycled aggregates implementation. Results indicate a maximum reduction in compressive strength for fully saturated cases, higher reliability in case of $7 \%$ saturation for rebound values and a higher level of water penetration for maximum recycled aggregate application for fully saturated cases.

Keywords: concrete, compressive strength, recycled aggregate, degree of saturation, surface hardness.

\section{Introduction}

Nowadays the evolution of the construction industry demands higher amount of raw materials and results more demolition waste. According to Eurostat, the construction demolition waste produced in Europe is estimated to be app. 970 million tons/year (Sonigo et al, 2010). Hence, the building demolition market is increasing gradually to meet mainly economic requirements. Waste contamination and density is the starting point of the estimation of cost for waste operators. For instance, the delivered price to the waste operators for clean aggregate starts from 5.5 euro/ton up to 129 euro/ton for contaminated aggregate based on bulk loose densities of $200 \mathrm{~kg} / \mathrm{m}^{3}$. Thus, the cost stimulates more the recycling industry and challenges more the deconstruction techniques (Lourenço, 2007). Concrete is the most common material used in construction industry, but it is not considered environmentally friendly due to the use of naturally produced aggregates and high volume of primary energy by producing of cement as binder material. Since aggregates cover almost 75 V\% of concrete constituents (Pekár, 2013a; 2013b; 2013c), the focus today is to standardize and provide reliable recommendations for the application of recycled aggregates (RA). Also, limitations and reliability of crushed bricks must be considered in terms of impurities, water absorption and other properties (Nemes, Török, 2014; Nemes, 2015). An investigation regarding physical and mechanical properties of concrete made with and without RA and natural aggregate (NA) is the target of this paper. Compressive strength, surface hardness and watertightness were studied during the experiments.

\section{Experimental procedure}

\subsection{Materials}

Danube aggregates, crushed bricks aggregates, natural sand, slag cement, tap water and polycarboxylate-based high range water reducing admixtures were applied as raw materials to produce concrete mixtures. Local natural sand and recycled bricks powder is used as fine aggregates with a fraction between (0-4 mm). A fixed proportion of particle size distribution is divided as $45 \%$ (0-4 mm), 12\% (4-8 $\mathrm{mm}), 30 \%$ (8-16 mm), and $13 \%(16-32 \mathrm{~mm})$ by weight, respectively. Crushed bricks were used as coarse aggregates with a maximum particle size of $\mathrm{D}_{\max }=32 \mathrm{~mm}$. Regarding physical properties, specific gravity of $\mathrm{NA}$ and RA are 2.65 and $1.95 \mathrm{~g} / \mathrm{cm}^{3}$, respectively.

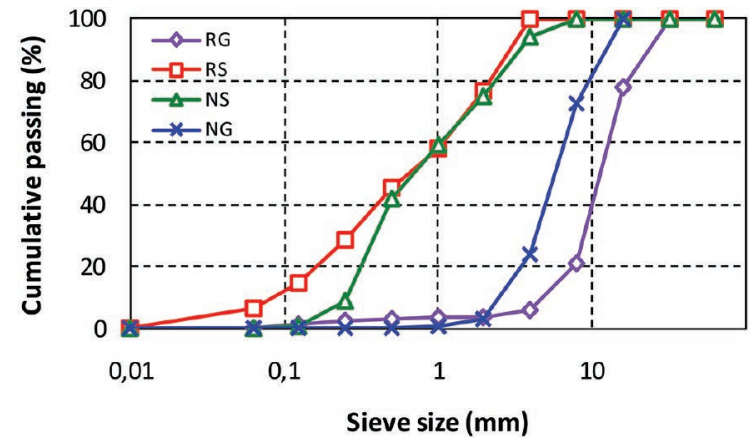

Fig. 1. Grading of natural and recycled aggregates.

1. ábra Természetes és újrahasznositott adalékanyagok szemeloszlása. 
Lafarge CEM III/B 32,5 N - LH/SR was used in the concrete mixtures. It has a special characteristic of low heat of hydration and sulphate resistance. New generation high range water reducing admixture (Sika ViscoCrete) was applied. It is an aqueous solution of modified polycarboxylates. In this study, a total of ten concrete mixtures were prepared with various conditions. Grading curves are represented by Fig. 1 and the water-to-cement ratio was constant $(\mathrm{w} / \mathrm{c}=0.5)$. For the aggregate types the following nomenclature is used: natural gravel (NG), recycled gravel (RG), natural sand (NS), recycled sand (RS). The aggregate content and saturation degree were variable parameters. For more details, mixture proportions are shown in Table 1.

\section{Mix NG (\%) RG (\%) NS (\%) RS (\%) Agg. volume $\left(1 / \mathrm{m}^{3}\right)$}

\begin{tabular}{lccccc} 
C1A* $^{*}$ & 0 & 100 & 100 & 0 & 72.2 \\
\hline $\mathbf{C 2 A}^{*}$ & 0 & 100 & 100 & 0 & 68.2 \\
\hline $\mathbf{C 3 A}^{*}$ & 0 & 100 & 55.55 & 44.44 & 72.2 \\
\hline $\mathbf{C 4 A}^{*}$ & 0 & 100 & 55.55 & 44.44 & 68.2 \\
\hline $\mathbf{C 1 B}^{* *}$ & 0 & 100 & 100 & 0 & 72.2 \\
\hline $\mathbf{C 2 B}^{* *}$ & 0 & 100 & 100 & 0 & 68.2 \\
\hline $\mathbf{C 3 B}^{* *}$ & 0 & 100 & 55.55 & 44.44 & 72.2 \\
\hline $\mathbf{C 4 B}{ }^{* *}$ & 0 & 100 & 55.55 & 44.44 & 68.2 \\
\hline $\mathbf{C 1}$ & 100 & 0 & 100 & 0 & 72.2 \\
\hline $\mathbf{C 2}$ & 100 & 0 & 100 & 0 & 68.2
\end{tabular}

*: 7\% water saturation

$* *$ : $100 \%$ water saturation

Table 1. Concrete mixture composition 1. táblázat. Betonösszetételek

\subsection{Testing procedure}

Several techniques of evaluation were executed in order to understand the behavior of the material properties. Nondestructive tests assessment in which N-type Schmidt rebound hammer was applied to record the rebound value. The rebound hammer test was carried out in horizontal direction on 11 different points located at the tested area while surfaces perpendicular to the direction of the test were fixed from both sides. It was directly followed by the compressive strength test using Form-Test Alpha 3000 universal testing machine with a load capacity of $3000 \mathrm{kN}$. The rate of loading was fixed to 11.25 $\mathrm{kN} / \mathrm{s}$. According to referred protocol (EN 12504-2), specimens corresponding to $150 \mathrm{~mm}$ size cubes were evaluated at the ages 7 and 28 days. Watertightness test was performed based on EN 12390-8 standard. At 28 days, $150 \mathrm{~mm}$ size cubes were tested under water pressure ( 5 bar) for 72 hours. After the test, specimens were split in half and the maximum depth of water penetration was recorded to the nearest $\mathrm{mm}$.

\subsection{Fresh concrete properties}

In overall, almost all the tested mixes show an efficient workability, no segregation or bleeding were noticed while performing the slump test. The slump of the fresh concrete was measured according to EN 12350-2 standard. Based on the results recorded in Fig. 2, a variety of $52-59 \mathrm{~cm}$ slump values are obtained where it has been planned earlier to keep a range of $(50-60 \mathrm{~cm})$. However, regarding C2B mixture which is considered fully saturated, a peak of $70 \mathrm{~cm}$ slump was observed. Concrete mixtures where RA was applied, a moderate reduction in weight of $11 \%$ was found for the fresh wet density with respect to the NA concrete mixtures. For more observation, Fig. 2 illustrates all the cases.

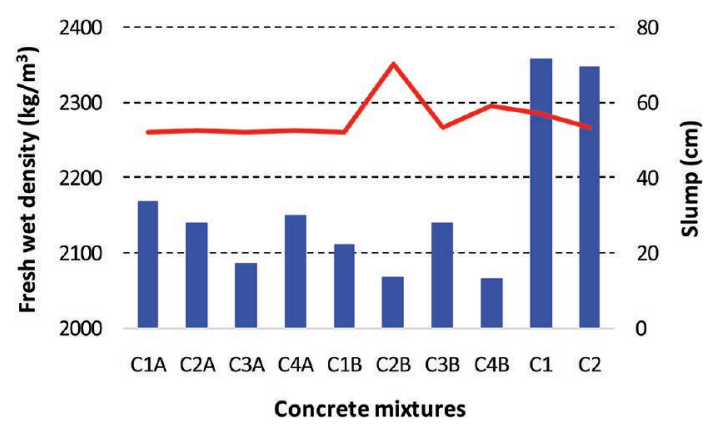

Fig. 2. Fresh wet density and slump measurements for different mixtures 2. ábra. Frissbeton testsürüség és roskadás erdmények

\subsection{Hardened state}

\subsubsection{Compressive strength}

The compressive strength values with respect to recycled aggregate content of all concrete mixtures are presented in Fig. 3. Obviously, the higher the amount of recycled aggregate used, the lower the compressive strength of concrete.

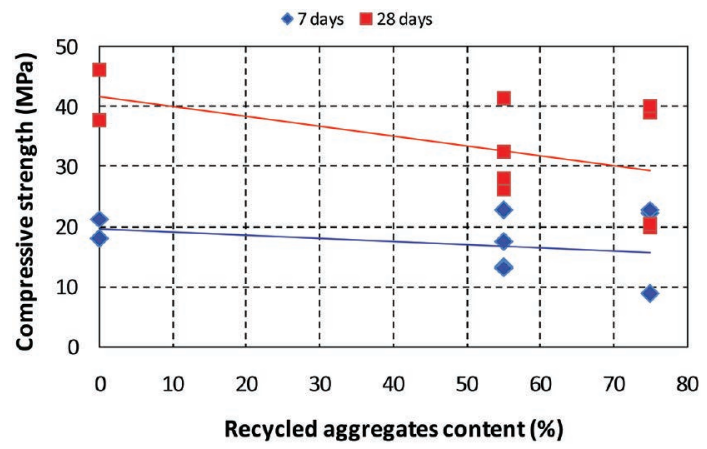

Fig. 3. Concrete compressive strength variation with recycled aggregate substitution 3. ábra Újrahasznositott adalékanyaggal készített betonok nyomószilárdsága

At the age of 7 days, concrete mixtures with RA exhibit an average decrease of $22 \%$ in compressive strength with respect to normal concrete mixtures. On the other hand, an average decrease of $35 \%$ in compressive strength is corresponding to the age of 28 days. In order to understand the behavior for each case, partially and fully saturated cases were separated as shown in Fig. 4. At the age of 7 days, fully saturated mixtures indicate a significant descending branch to reach $122 \%$ drop in compressive strength at the maximum rate of RA substitution. However, in case of $7 \%$ degree of saturation, a slight increase of $14.2 \%$ in compressive strength is reached at maximum rate of RA substitution. The explanation of the latter behavior is mainly related to hydration and effect of the water content to the curing process and water-to-cement ratio. Yet, due to the excess amount of water in fully saturated case, the bond between the recycled aggregate and cement matrix is weakened, creating a high local $\mathrm{w} / \mathrm{c}$ in the vicinity of the particles (Poon et al, 2004). At the age 
of 28 days, fully saturated mixtures show a noticeable variation in strength, reaching $107 \%$ drop in compressive strength at the maximum rate of RA substitution. In case of $7 \%$ degree of saturation, insignificant decrease of $13 \%$ in compressive strength is reached at maximum rate of RA substitution. To justify the behavior of $7 \%$ partially saturated condition, the cement content from mortar residue of crushed bricks already applied as sand material played an important role in increasing the cement content. The absorption of RA enhances the decrease in the water-to-cement ratios yet obtaining a relatively high strength with high amount of RA substitution.

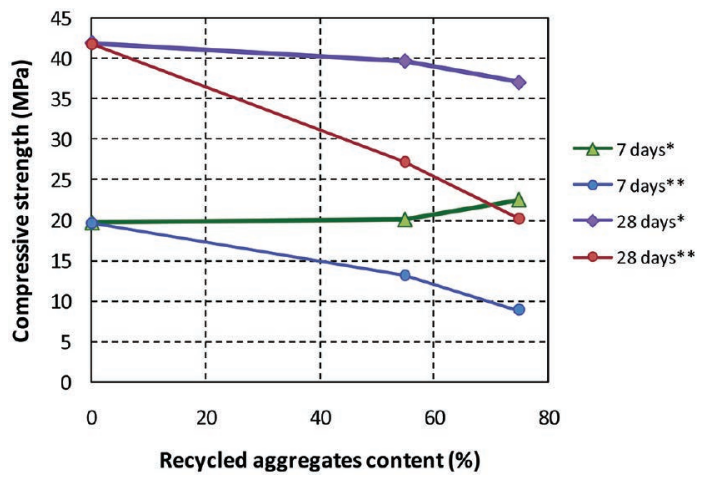

Fig. 4 Concrete compressive strength variation with recycled aggregate substitution for separate saturation conditions

4. ábra Beton nyomószilárdság változása az újrahasznositott adalékanyag mennyiségének és telítettségének függvényében

*: $7 \%$ water saturation

$* *: 100 \%$ water saturation

\subsubsection{Surface hardness}

Many factors directly affect the rebound hardness such as mixtures components (aggregate type and content, cement type), or the member characteristics (density, surface texture, age, mass and others). In this study mainly the aggregate type and condition is taken into consideration (Bungey, 1982; Szilágyi, Borosnyói, 2009; Szilágyi et al, 2011). Fig. 5 shows that $7 \%$ saturated mixtures are more reliable toward the linear function by Hobbs and Kebir (proposed for NA concretes with $\mathrm{w} / \mathrm{c}=0.5$ and $350 \mathrm{~kg} / \mathrm{m}^{3} \mathrm{CEM} 42.5 \mathrm{~N}$ cement content) with respect to fully saturated cases (Hobbs, Kebir, 2006). This is due to water reduction in concrete mix that results an improvement of the resistance of concrete surface.

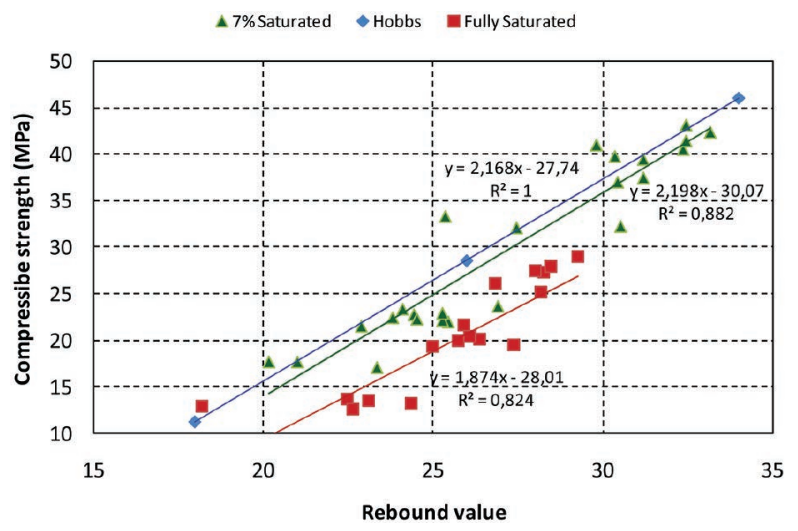

Fig. 5. Rebound value vs. compressive strength of all concrete mixtures 5. ábra Schmidt kalapácsos visszapattanási értékek és nyomószilárdság összefüggések

\subsubsection{Water penetration under pressure}

Compared to those of the control mixture $\mathrm{C} 1$ and $\mathrm{C} 2$, depth of water penetration under pressure of RA mixtures increased with increasing replacement level of RA up to $136 \%$ in average. This effect is due to the higher porosity of the RA than that of the NA (Pankhardt, 2001; Pankhardt, Nehme, 2002; Jani et al 2010). However, in the comparison between fully saturated and $7 \%$ saturated concrete mixtures, le latter perform a higher average penetration depth by $108 \%$. For more information, Fig. 6 illustrates average penetration depth of each case separately.

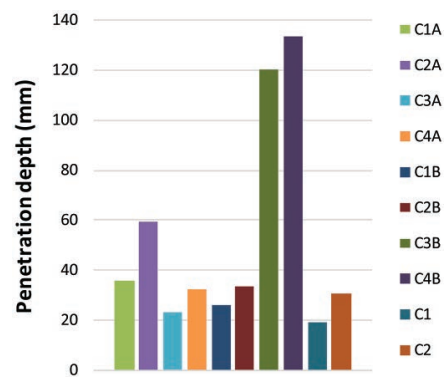

Fig. 6. Penetration of water under pressure for all concrete mixtures 6. ábra Nyomás alatti vízbehatolás mértéke a vizsgált betonokon

\section{Conclusions}

Based on the present investigation concerning the effect of coarse and fine crushed bricks as aggregate in concrete mixtures in different levels of saturation, the following conclusions can be drawn:

- In comparison with natural aggregates, recycled brick aggregates hold a lower bulk density value and a higher water absorption.

- Fresh wet densities of crushed bricks concretes show lower value of an average of $11 \%$ with respect to natural aggregate concrete.

- Compressive strength of crushed bricks concretes in case of fully saturated aggregates exhibits a noticeable decrease of $107 \%$ with respect to natural aggregate mixtures at 28 days.

- Relationship between compressive strength and rebound value for both fully saturated and $7 \%$ saturated aggregates was found to be linear in the tested range.

- Watertightness test confirms that higher penetration depth occurs due to the higher porosity, mainly in fully saturated case.

\section{References}

Bungey, T. H. (1982): Testing of Concrete Structures, Surrey University Press. EN 12350-2. Testing fresh concrete - part 2: Slump-test.

EN 12390-8. Testing hardened concrete - depth of penetration of water under pressure.

EN 12504-2. Testing concrete in structures. Non-destructive testing. Determination of rebound number.

Hobbs, B. - Kebir, M. T. (2006): Non-destructive testing techniques for the forensic engineering investigation of reinforced concrete buildings, Forensic Science International, Vol. 167, No. 2-3, pp. 167-172. http://dx.doi.org/10.1016/j.forsciint.2006.06.065

Jani, S. G. - Serestyén, T. - Pankhardt, K. - Kovács, J. (2010): Újrahasznosított adalékanyagú betonok In: Pokorádi L. (ed.) MTEKMR 2010 Conference, Nyíregyháza, Hungary, 2010.05.19, 2010. pp. 325-332. 
Lourenço, C. (2007): Optimizing demolition systems, deconstruction, MSc Thesis, Lisbon, Portugal, Instituto Superior Técnico. (in Portuguese)

Nemes, R. (2015): Könnyűbetonok fagyasztásvizsgálatának érdekességei, Építöanyag - Journal of Silicate Based and Composite Materials, Vol. 67. No. 1, pp. 24-27. http://dx.doi.org/10.14382/epitoanyag-jsbcm.2015.5

Nemes, R. - Török, B. (2014): Betonacél tapadása különböző könnyü adalékanyagok alkalmazása esetén, Építőanyag - Journal of Silicate Based and Composite Materials, Vol. 66. No. 1, pp. 7-12. http://dx.doi.org/10.14382/epitoanyag-jsbcm.2014.2

Pankhardt, K. (2001): Recycling of concrete, In: Végh L (ed.) Environmentally Compatible Structures. Conference: Prague, Czech Republic, 2001.05.24 -2001.05.25. pp. 35-41.

Pankhardt, K. - Nehme, S. G. (2002): Strength and deformation of recycled concrete. In: Proceedings of fib Congress Osaka, pp. 59-68.

Pekár, G. (2013a): Simple basic model for concrete and its application. 1. Content indicators of concrete mixtures and mixing plant observations, Építőanyag, Vol. 65. No. 2, pp. 52-60. http://dx.doi.org/10.14382/epitoanyag-jsbcm.2013.12

Pekár, G. (2013b): Simple basic model for concrete and its application. 2. Factors that influence compressive strength and drying shrinkage, Építőanyag, Vol. 65. No. 3, pp. 76-84.

http://dx.doi.org/10.14382/epitoanyag-jsbcm.2013.15

Pekár, G. (2013c): Simple basic model for concrete and its application. 3. Factors aff ecting consistency, material balance equations and mix design, Építőanyag, Vol. 65. No. 4, pp. 118-126.

http://dx.doi.org/10.14382/epitoanyag-jsbcm.2013.22

Poon, C. S. - Shui, Z. H. - Lam, L. - Fok, H. - Kou, S. C. (2004): Influence of moisture states of natural and recycled aggregates on the slump and compressive strength of concrete, Cement and Concrete Research, Vol. 34 , No. 1, pp. 31-36. http://dx.doi.org/10.1016/S0008-8846(03)00186-8

Sonigo, P. - Hestin, M. - Mimid, S. (2010): Management of Construction and Demolition Waste in Europe, Brussels, Stakeholders Workshop.

Szilágyi, K. - Borosnyói, A. (2009): 50 years of experience with the Schmidt rebound hammer, Concrete Structures, Vol. 10, pp. 46-56.
Szilágyi, K. - Borosnyói, A. - Zsigovics, I. (2011): Rebound surface hardness of concrete: Introduction of an empirical constitutive model, Construction and Building Materials, Vol. 25, No. 5, pp. 2480-2487. http://dx.doi.org/10.1016/j.conbuildmat.2010.11.070

Ref::

El Mir, Abdulkader - Balczó, Gáspár - Nehme, Salem Georges: Effect of saturation degree of recycled aggregates on concrete properties Építőanyag - Journal of Silicate Based and Composite Materials, Vol. 67, No. 2 (2015), 58-61.p. http://dx.doi.org/10.14382/epitoanyag-jsbcm.2015.9

Újrahasznosított adalékanyagok telítettségi fokának hatása a betontulajdonságokra

A cikkben a szerzôk azt vizsgálják, hogy milyen hatást gyakorol az újrahasznosított, tört tégla adalékanyag a betonok jellemzóire, illetve, hogy az újrahasznosított adalékanyag víztartalma hogyan befolyásolja az alkalmazhatóságot. Két eltérố víztartalmi állapotot tanulmányoznak: a légszáraz állapotot (amely $7 \mathrm{~m} \%$ víztartalmat jelent), illetve a víztelített állapotot. Az újrahasznosított adalékanyag szitálással szúk frakciókban került adagolásra: 0/4 mm, 4/8 mm, 8/16 mm és 16/32 mm frakciók készültek. A természetes finom és durva adalékanyag 55 és 75 V\%-át helyettesítették újrahasznosított adalékanyaggal. Vizsgált betontulajdonságok: nyomószilárdság, felületi keménység, vízzáróság. A vizsgálatok eredményei szerint a legnagyobb szilárdságcsökkenést a víztelített adalékanyag alkalmazása eredményezi. A Schmidt-kalapácsos visszapattanási érték és a nyomószilárdság között lineáris összefüggés kapható a vizsgált tartományokban. Az újrahasznosított adalékanyag nagyobb porozitása miatt a nyomás alatti vízbehatolás mértéke nô, a vízzáróság ezzel romlik. Kulcsszavak: beton, nyomószilárdság, újrahasznosított adalékanyag, telítettségi fok, felületi keménység.
International Symposium Non-Destructive Testing in Civil Engineering (NDT-CE)

September 15 - 17, 2015, Berlin, Germany wuw ndt-ce2015. net

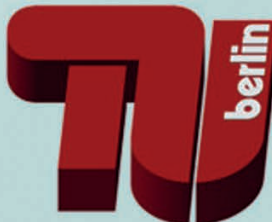

The International Symposium Non-Destructive Testing in Civil Engineering returns to Berlin. It brings together experts from all areas in this fast developing area of research and application. Researchers, manufacturers, service providers, owners of structures and those active in training, validation and standardization are welcome to share latest research and developments.

The symposium provides an open space for exchange of ideas, new developments, testing needs from owners, asset management and from research.

\section{Sessions Topics}

- High speed deflection devices used for pavement evaluation

- Nonlinear Ultrasonics

- NDT of concrete properties, On site concrete evaluation

- Nuclear Structures

- Chemical Analysis and LIBS

- Corrosion

- Tendons and Defects in Prestressed Elements

- Moisture

- Foundations, Pile Testing

- Ultrasonics

- Ground Penetrating Radar
- Data Analysis: Coda Wave Interferometry, Data Fusion, Reverse Time Migration

- Bridge Inspection on novel and non-traffic-invasive inspection of bridge decks

- Impact Echo and related Methods

- Regulation, Training, Guidelines

- Validation

- Thermography

- Structural Monitoring for Condition Assessment of Existing and New Structures

- Modelling, Simulation, Inverse Solutions

- Automation, Robitic Inspection

- Teaching in NDT in Civil Engineering 